\title{
Livro arte: restituir memórias século XX-XXI
}

Art book: returning memories XX-XXI

century

Antonio José dos Santos Junior ${ }^{1}$

\begin{abstract}
1 Mestre em Artes Visuais (PPGART/UFSM), linha de pesquisa Arte Visualidade com ênfase em Poéticas Visuais, bolsista CAPES 2018-20. Artista Visual - Desenho e Plástica (UFSM) com período sanduíche na Faculdade de Belas Artes da Universidade do Porto, Portugal (FBAUP). Integrante dos grupos de pesquisas: Arte Impressa e Ecologia CNPq/UFSM / Processos Pictóricos CNPq/UFSM. Tem interesse em investigar processos de criação e pintura na contemporaneidade.

LATTES: http://lattes.cnpq.br/1715724412555768 - ORCID: https://orcid org/0000-0001-5641-7663
\end{abstract}




\title{
Resumo
}

Essa série de imagens, faz parte de uma investigação realizada entre 2013-2017, partindo de apropriações de fotografias de arquivos pessoais e familiares, conhecidos e mesmo desconhecidos. Trata-se de entrar no universo pessoal e visual proposto pelas fotografias, no seu cotidiano e intimidade, atuando de modo dialogante e interativo com essas mesmas histórias, reconstruindo e construindo outras memórias. Nesse sentido, para além dos personagens, os objetos e os lugares também fazem parte da construção da memória individual, sendo importante identificar e registrar tudo o que se move ao seu redor e desta forma contribuir para que essa narrativa da memória ganhe força. A identificação do público com objetos, ambientações e as poses estáticas levam os mesmos a uma aproximação do universo da memória fazendo referência a vivências pessoais, culturais e nostálgicas. Experimentações realizadas em xilogravura, litografia, gravura em metal e pinturas a óleo, origina uma descoberta de um território. Um livro arte, criado a partir de novas fotografias concebidas desses trabalhos... gentes e cenas que despertam novas leituras e, acentuam a intenção dialogante entre o que se conhece e, principalmente com o que, sendo desconhecido, parece muito familiar.

\section{Palavras-chave}

Restituir, Processo Criativo, Memórias, Livro Arte.

\begin{abstract}
This series of images is part of an investigation carried out between 2013-2017, starting with appropriations of photographs from personal and family files, known and even unknown. It is about entering the personal and visual universe proposed by the photographs, in their daily life and intimacy, acting in a dialogical and interactive way with these same stories, reconstructing and building other memories. In this sense, in addition to the characters, objects and places are also part of the construction of individual memory, which is important to identify and record everything that moves around them and thus contribute in order to that narrative of memory to gain strength. The public's identification with objects, environments and static poses lead them to an approximation of the universe of memory making reference to personal, cultural and nostalgic experiences. Experiments performed in woodcut, lithography, metal engraving and oil paintings, originate a discovery of a territory. An art book, created from new photographs conceived of these works ... people and scenes that awaken new readings and, emphasize the dialogue intention between what is known and, especially with what, being unknown, seems very familiar.
\end{abstract}

\section{Keywords}

Restitute, Creative process, Memories, Art Book.

ISSN: 2447-1267 

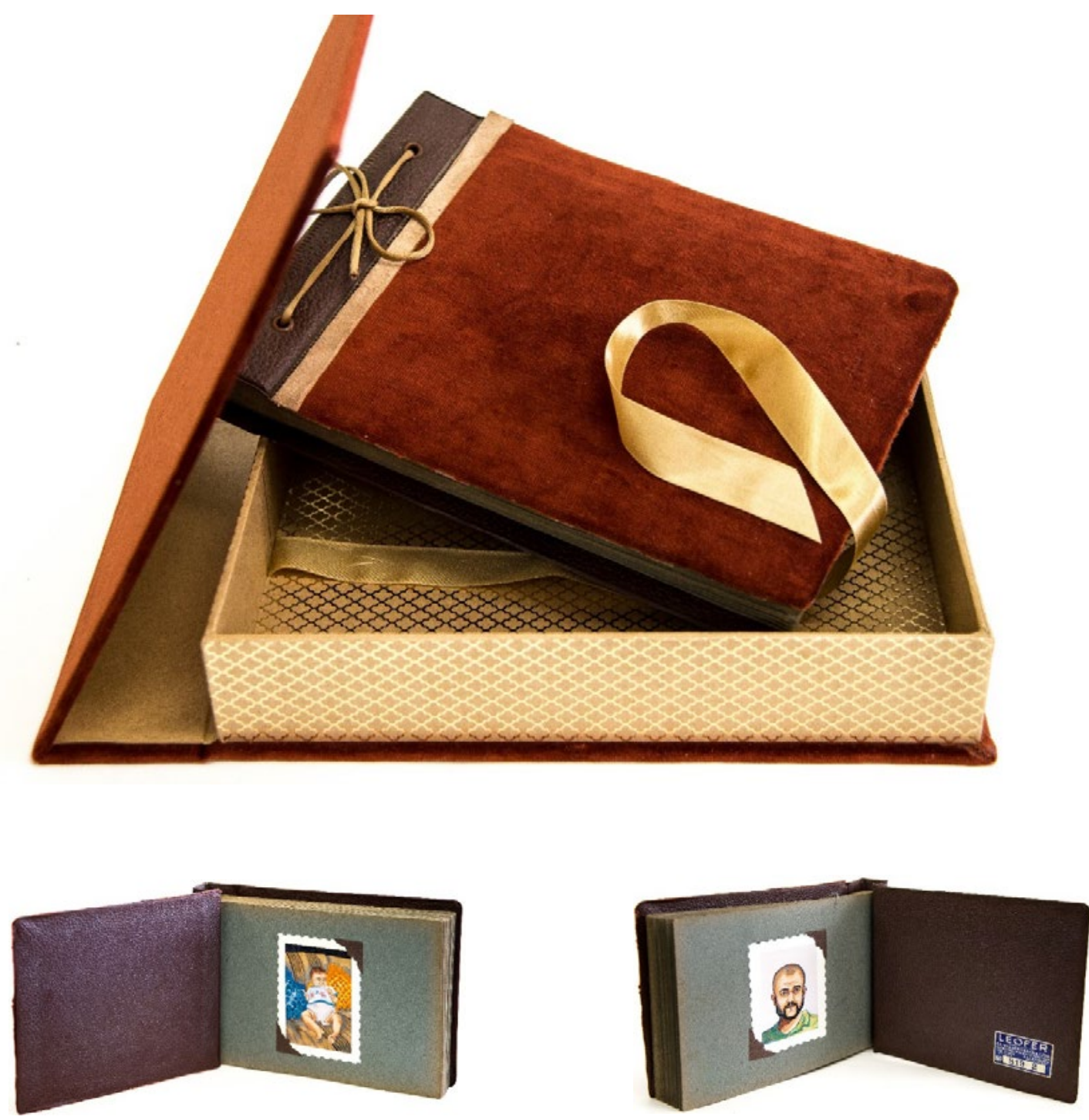

Memórias: século XX-XXI

2013-17

Livro arte - técnica mista

48 páginas. $30 \times 21,5 \times 6 \mathrm{~cm}$

Acervo pessoal

1 Este trabalho participou das seguintes exposições coletivas: Em 2017, "5 anos - IN:Transitivos" / Exposição comemorativa do Grupo de Pesquisa Arte Impressa CNPq/UFSM na Sala de Exposições Claudio Carriconde CAL/ UFSM, Santa Maria, RS. Em 2019, "21 $1^{a}$ Mostra Cascavelense de Artes Plásticas" no Museu de Arte de Cascavel MAC, Cascavel, PR. 

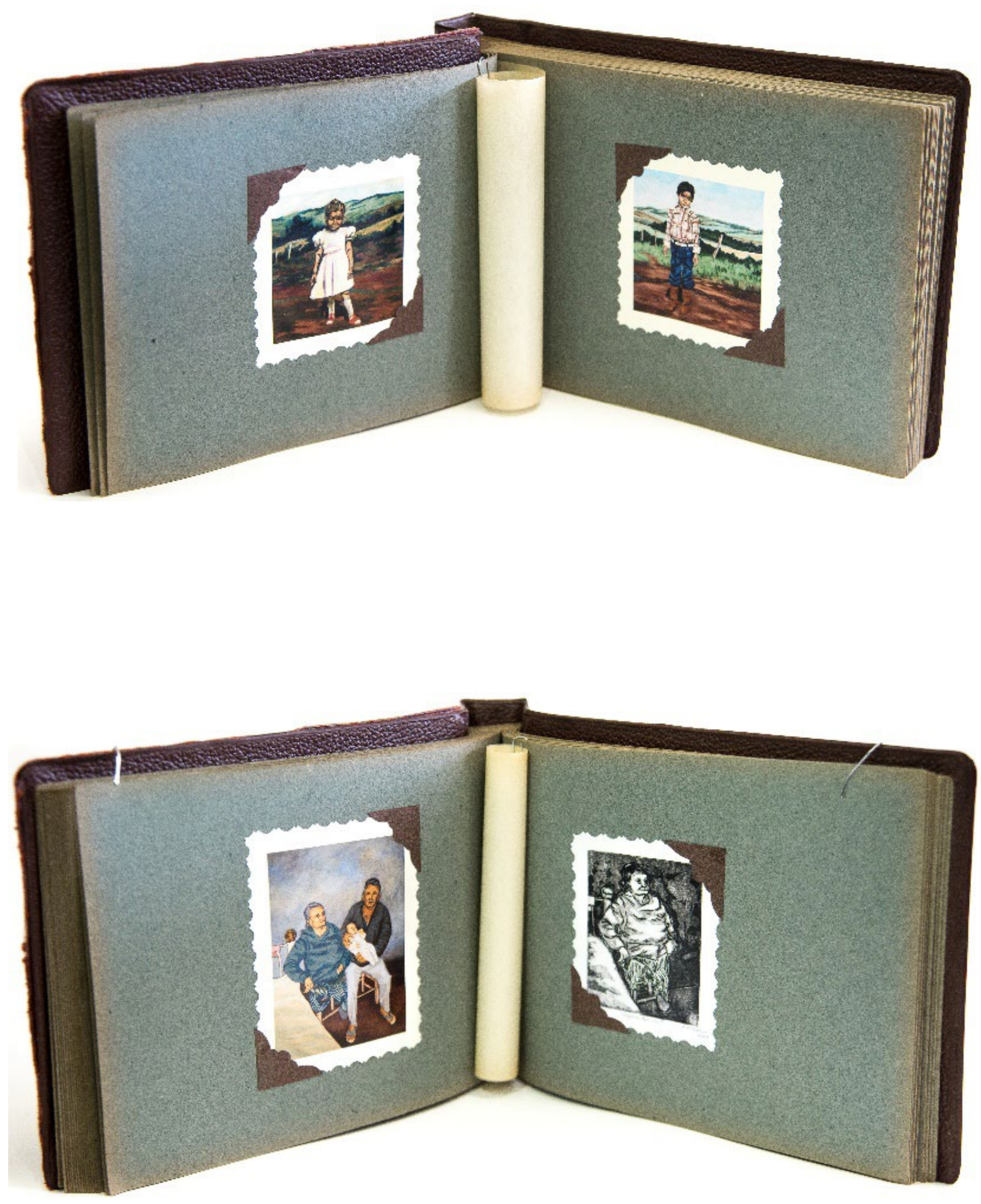

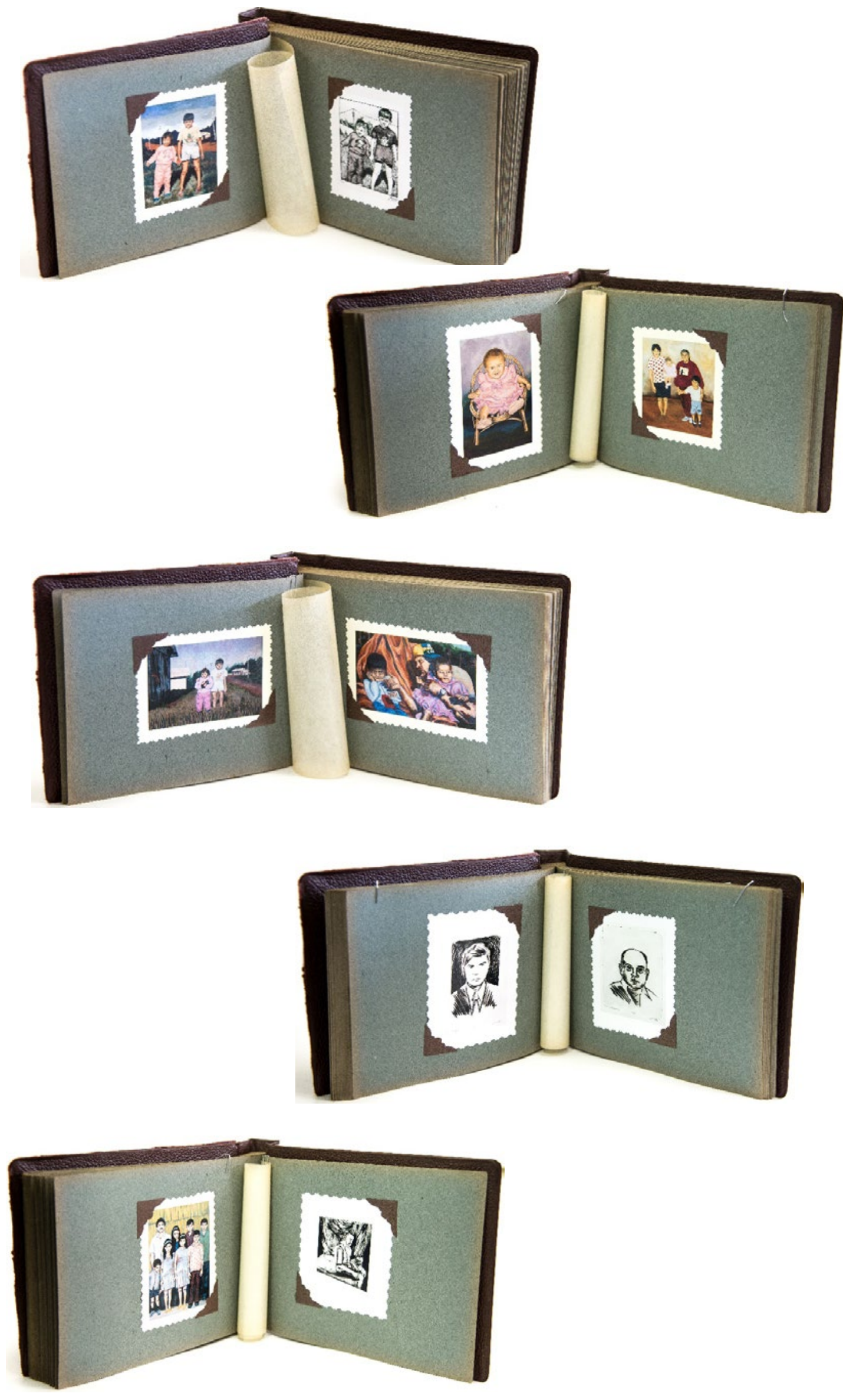

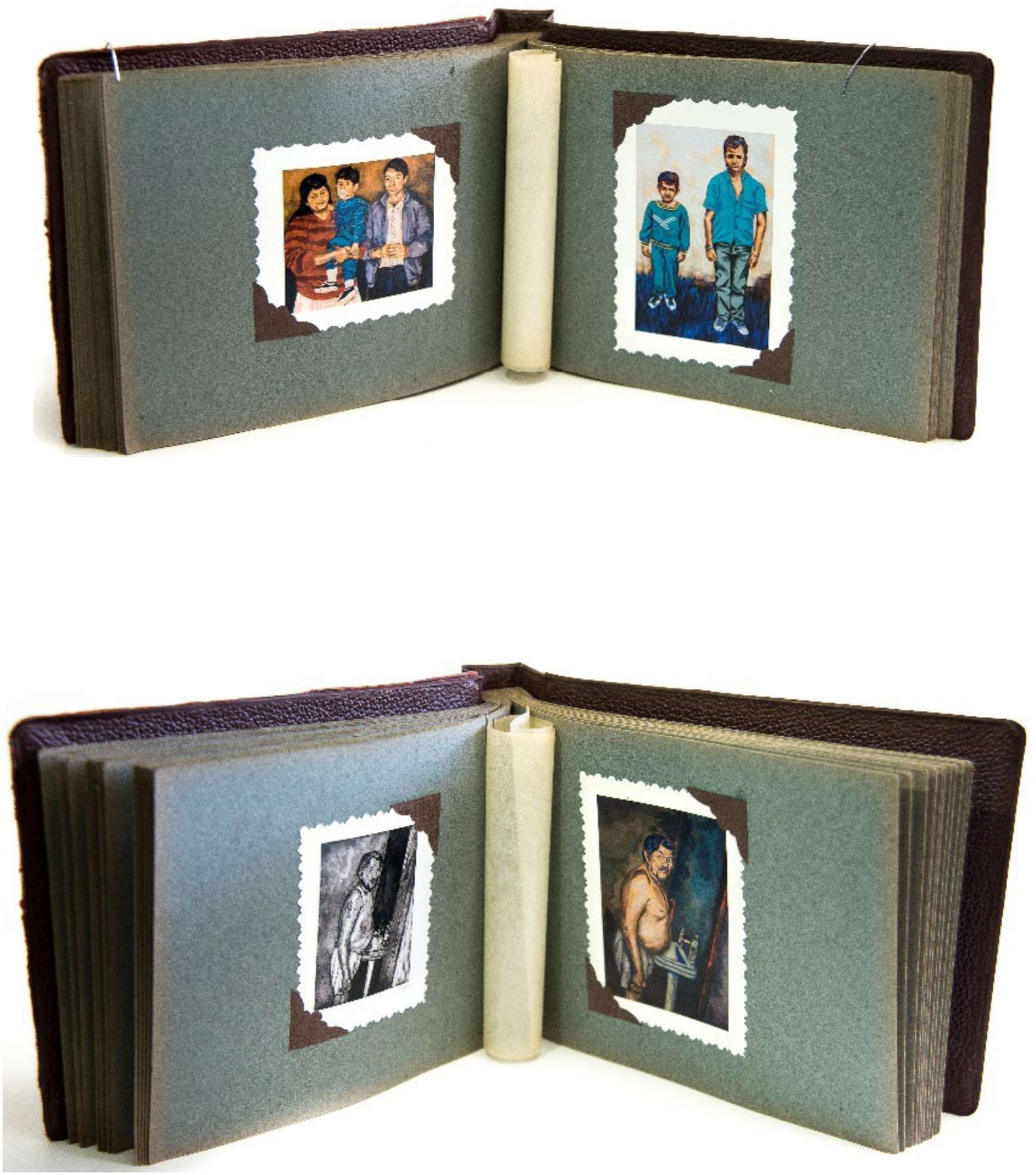

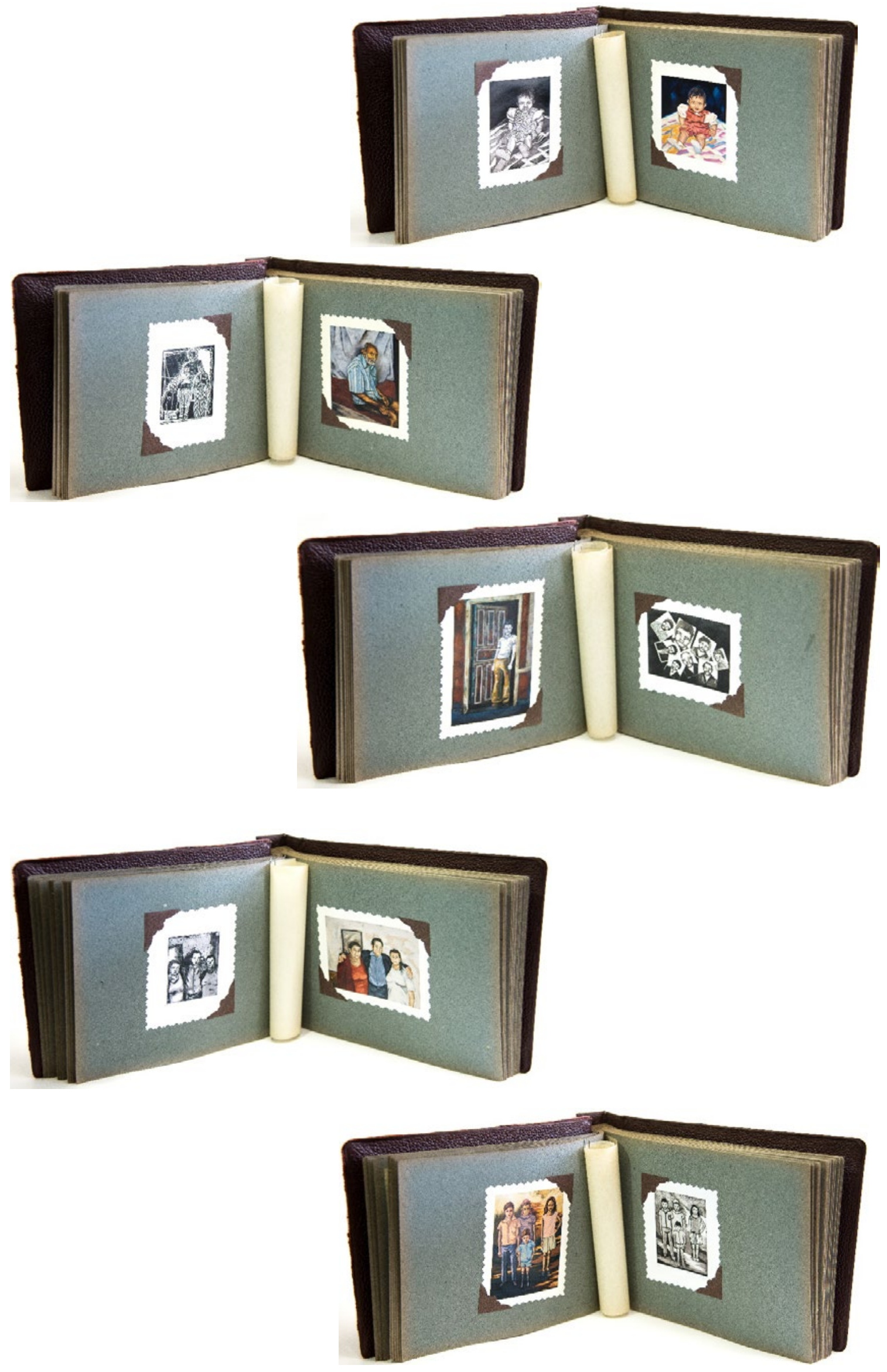

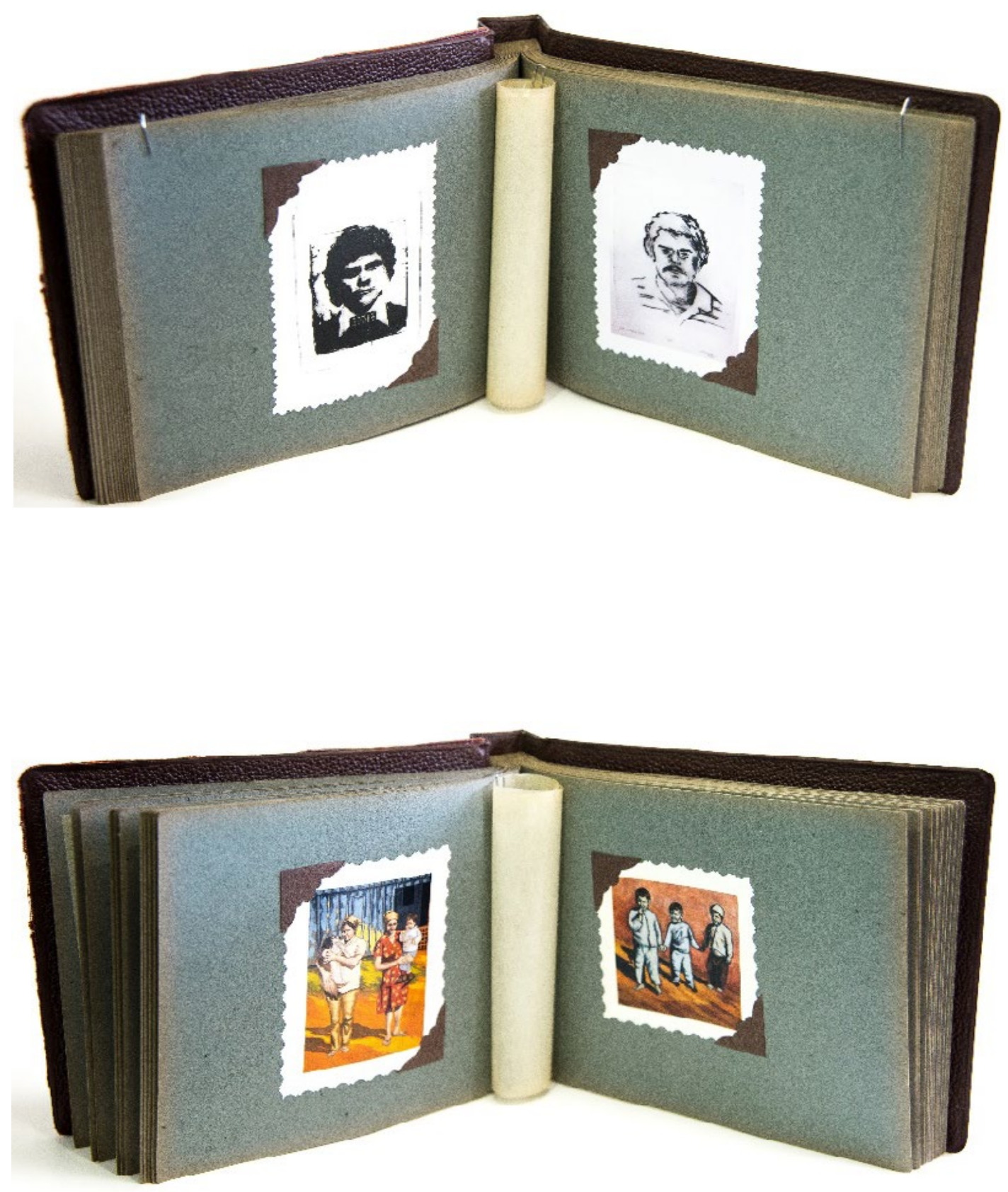

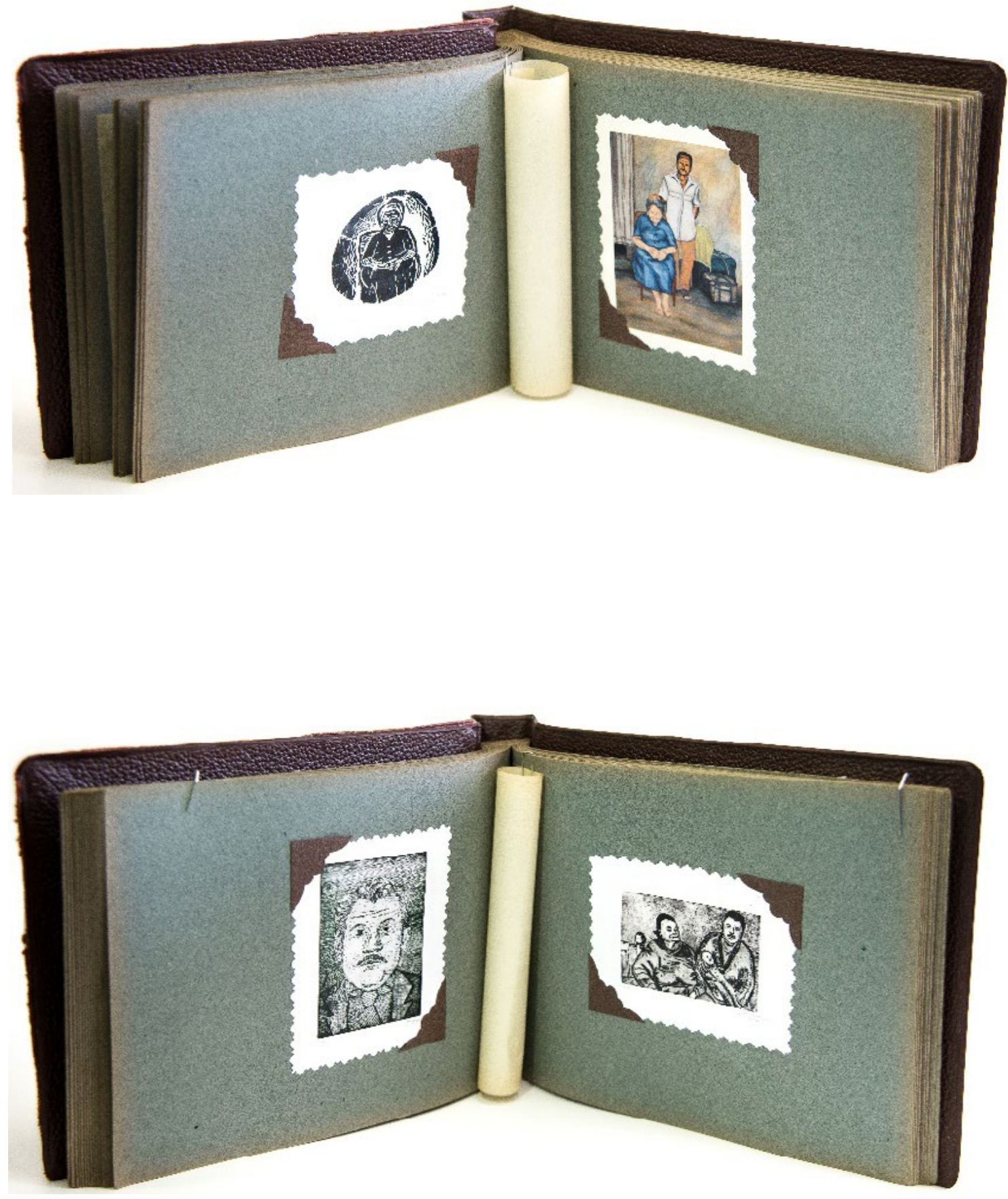

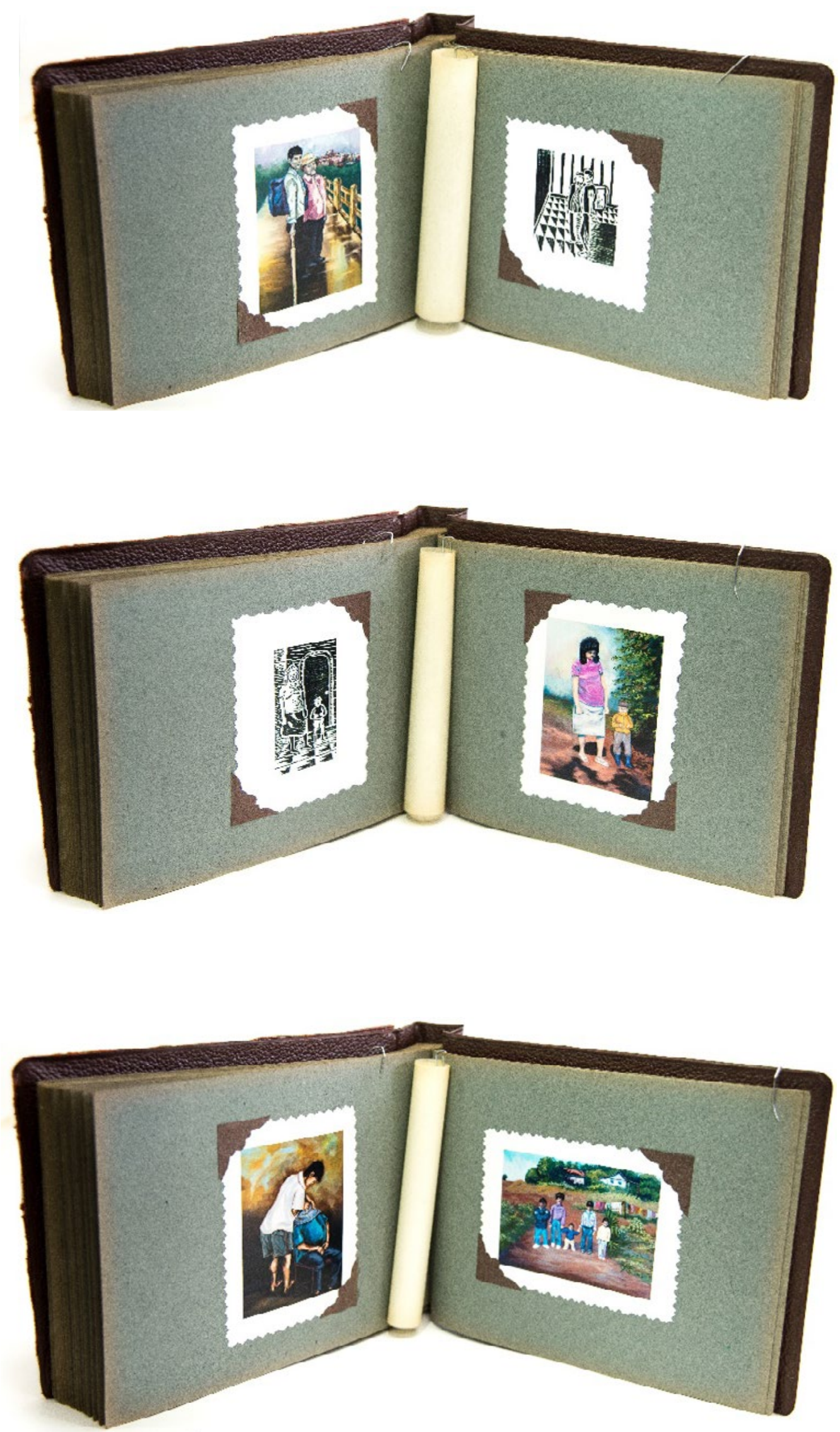

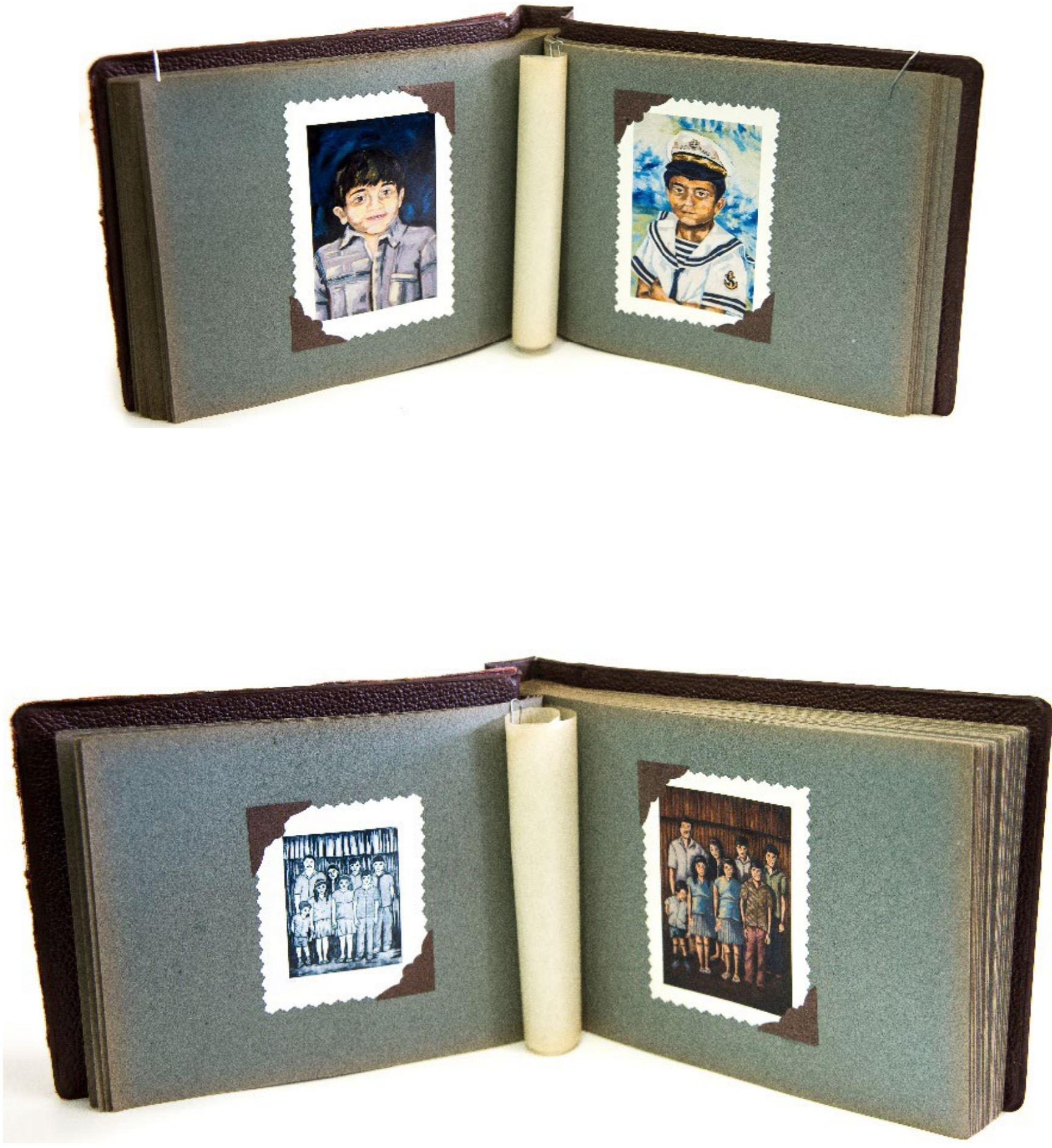

Recebido em 06 de junho de 2020.

Aprovado em 22 de julho de 2020. 